\title{
The Application of Embelin for Cancer Prevention and Therapy ${ }^{\dagger}$
}

\author{
Jeong-Hyeon Ko ${ }^{1}$, Seok-Geun Lee ${ }^{1}{ }^{\mathbb{D}}$, Woong Mo Yang ${ }^{1}$, Jae-Young Um ${ }^{1}$, Gautam Sethi ${ }^{2,3,4, *}$, \\ Srishti Mishra ${ }^{4}$, Muthu K. Shanmugam ${ }^{4}$ and Kwang Seok Ahn ${ }^{1, *}$ (iD) \\ 1 College of Korean Medicine, Kyung Hee University, 24 Kyungheedae-ro, Dongdaemun-gu, Seoul 02447, \\ Korea; gokjh1647@gmail.com (J.-H.K.); seokgeun@khu.ac.kr (S.-G.L.); wmyang@khu.ac.kr (W.M.Y.); \\ jyum@khu.ac.kr (J.-Y.U.) \\ 2 Department for Management of Science and Technology Development, Ton Duc Thang University, \\ Ho Chi Minh City 700000, Vietnam \\ 3 Faculty of Pharmacy, Ton Duc Thang University, Ho Chi Minh City 700000, Vietnam \\ 4 Department of Pharmacology, Yong Loo Lin School of Medicine, National University of Singapore, \\ Singapore 117600, Singapore; srishti.mishra@u.nus.edu (S.M.); phcsmk@nus.edu.sg (M.K.S.) \\ * Correspondence: gautam.sethi@tdt.edu.vn or phcgs@nus.edu.sg (G.S.); ksahn@khu.ac.kr (K.S.A.) \\ + Running Title: Potential Antineoplastic Effects of Embelin.
}

Received: 12 February 2018; Accepted: 8 March 2018; Published: 9 March 2018

\begin{abstract}
Embelin is a naturally-occurring benzoquinone compound that has been shown to possess many biological properties relevant to human cancer prevention and treatment, and increasing evidence indicates that embelin may modulate various characteristic hallmarks of tumor cells. This review summarizes the information related to the various oncogenic pathways that mediate embelin-induced cell death in multiple cancer cells. The mechanisms of the action of embelin are numerous, and most of them induce apoptotic cell death that may be intrinsic or extrinsic, and modulate the NF- $\mathrm{BB}, \mathrm{p} 53, \mathrm{PI} 3 \mathrm{~K} / \mathrm{AKT}$, and STAT3 signaling pathways. Embelin also induces autophagy in cancer cells; however, these autophagic cell-death mechanisms of embelin have been less reported than the apoptotic ones. Recently, several autophagy-inducing agents have been used in the treatment of different human cancers, although they require further exploration before being transferred from the bench to the clinic. Therefore, embelin could be used as a potential agent for cancer therapy.
\end{abstract}

Keywords: Embelin; apoptosis; autophagy; cancer; cell signaling

\section{Introduction}

Embelin (2,5-dihydroxy-3-undecyl-1,4-benzoquinone) is a major active constituent obtained from the Embelia ribes Burm plant (specifically, its fruit), and has been evaluated for treating a range of cancer types [1] (Figure 1). Embelin is a non-toxic compound and is well tolerated up to a dose of $3 \mathrm{~g} / \mathrm{kg}$ b.w. No subacute oral toxicity was detected after $10 \mathrm{mg} / \mathrm{kg}$ of embelin was administered to rats for 10 weeks [2]. A short-term toxicity study of embelin showed that oral administration of it to cyclic female rats for six weeks at $120 \mathrm{mg} / \mathrm{kg}$ was not toxic overall; however, some increase in the levels of alkaline and acid phosphatase was observed [3]. When embelin was administered for 14 weeks at $50 \mathrm{mg} / \mathrm{kg}$ b.w., it was found to be toxic to hematopoietic cells [4]. However, in contrast, when emeblin was administered to monkeys, rats, and mice for six months, it was found to be non-toxic, and no hematological toxicity was observed [5]. In addition, acute toxicity studies of mice that had been administered oral doses of 50 and $100 \mathrm{mg} / \mathrm{kg}$ of embelin revealed no notable change in mortality and body weight [6]. The toxicity of embelin was also assessed in a study involving pancreatic-cancer xenograft mice, after the mice spent six weeks on a $450 \mathrm{mg} / \mathrm{kg}$ diet. Blood analyses showed normal 
liver and kidney function in embelin dietary groups, suggesting that embelin was well tolerated and did not induce apparent toxicity [7]. The pharmacokinetics of the intravenous and oral administration of potassium embelate $(20 \mathrm{mg} / \mathrm{kg}$ ) to rats revealed that the compound followed a biexponential kinetic sequence. The absorption was fast and complete (the bioavailability was 97\%), with the drug peak plasma level at $9 \mu \mathrm{g} / \mathrm{mL}$ at $0.28 \mathrm{~h}$. The disposition half-life was $11 \mathrm{~h}$ for oral administration and $9.5 \mathrm{~h}$ for intravenous injection [8]. In another study, the oral administration of $50 \mathrm{mg} / \mathrm{kg}$ of embelin to rats resulted in $130.39 \pm 6.51 \mu \mathrm{g} / \mathrm{mL}$ peak plasma concentration after $4.285 \mathrm{~h}$ [9]. The oral administration $(70 \mathrm{mg} / \mathrm{kg})$ of embelin to mice yielded its maximum concentration in plasma $(3.55 \pm 0.13 \mu \mathrm{g} / \mathrm{mL})$ $1 \mathrm{~h}$ after administration, but it then declined rapidly to $0.26 \pm 0.06 \mu \mathrm{g} / \mathrm{mL}$ at $3 \mathrm{~h}$ [7]. According to Gupta et al. [10] oral administration ( $75 \mathrm{mg} / \mathrm{kg} /$ day) of embelin for 30 days in rats resulted in the highest levels being in the kidneys, followed by the testes and intestines. Significant levels were observed in the brain, heart, and spleen. The level of embelin in all the organs was higher than after 15 days of treatment. The levels slowly declined in all of the organs after 30 days of embelin treatment, indicating slow elimination from the body. These results indicate that the possible accumulation of embelin in the tissues is one reason for its effective biological activities.

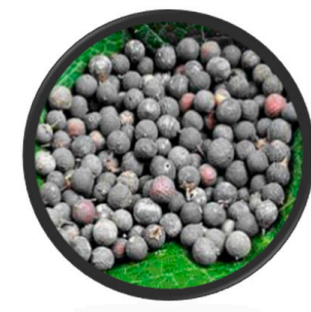

Embelia ribes False Black Pepper)

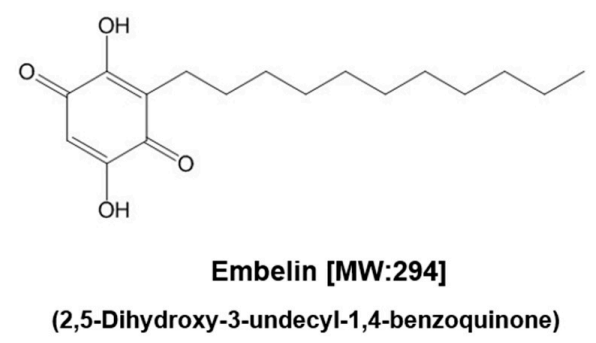

(2,5-Dihydroxy-3-undecyl-1,4-benzoquinone)

Figure 1. The chemical structure of embelin.

Numerous studies have determined the multiple biological properties of embelin, including anti-tumor, anti-inflammatory, analgesic, antidiabetic, and anti-oxidant effects [11-14]. A thorough computational-database screening revealed that, structurally, embelin could be characterized as a pharmacological inhibitor of XIAP (X chromosome-linked inhibitor-of-apoptosis protein) [15]. Embelin's anti-cancer properties have been observed in in vivo experiments in rodents (Table 1). Furthermore, several studies have evaluated embelin's role in anti-cancer combination therapy, highlighting the application of embelin in improving the efficacy of the treatment (Table 2). The anti-cancer activity of embelin is predominantly mediated by the modulation of various oncogenic transcription factors, inflammatory cytokines, growth factors, and protein kinases [16-19]. Strategically targeted cancer therapies are focused on investigating mechanisms associated with cell-growth and cell-death pathways. Imbalances in the coordination of cell proliferation and cell death can result in diseases such as cancer due to unrestrained cell growth and reduced cell death [20-23]. Apoptosis is the best-characterized and most evolutionarily conserved form of programmed cell death. It is a physiological phenomenon and is characterized by nuclear shrinkage, condensation and subsequent fragmentation, membrane blebbing, and formation of apoptotic bodies [21,24-26]. Resistance to apoptosis is a common phenomenon in numerous varieties of cancer, and is also the crucial element in tumorigenesis and therapy resistance [25,27-29]. Apoptotic pathways are, thus, legitimate focus areas for cancer therapy; predominantly natural agents like embelin can affect various cell-death pathways [28].

Autophagy, unlike apoptosis, is not synonymous with cell death, however. Autophagy is a catabolic process, highly conserved, of elimination of proteins and cellular organelles, and it includes macroautophagy, microautophagy, and chaperone-mediated autophagy [30,31]. Autophagy is also a process of cleansing the cells of unwanted cellular proteins by packaging them to lysosomes for 
degradation. Autophagy plays an important role in several physiological and pathological processes, such as cell survival, cellular metabolism, immunity development, and aging [31,32]. Autophagy accompanied by non-apoptotic cell death has been described in cancer cells [31,33,34]. Therefore, the induction of autophagy is as an attractive goal for cancer treatment and prevention. The induction of autophagic cell death and apoptosis as mechanisms of cancer prevention by embelin will now be discussed.

Table 1. In vivo anti-cancer effects of embelin.

\begin{tabular}{|c|c|c|c|c|}
\hline Cancer Model & Animal Model & Dose & Outcome & References \\
\hline & $\begin{array}{l}\text { DMH models in male and female } \\
\text { C57 mice }\end{array}$ & $\begin{array}{l}100 \mathrm{mg} / \mathrm{d} / \mathrm{kg} \text { body weight (b.w.) } \\
\text { mixed in diet for } 30 \text { weeks }\end{array}$ & $\begin{array}{l}\text { Tumor incidence } \downarrow \text {, Tumor } \\
\text { multiplicity } \downarrow \text {, Cox-2 } \downarrow ; \\
\text { PCNA } \downarrow ; \text { c-Myc } \downarrow ; \text { Survivin } \downarrow\end{array}$ & [35] \\
\hline Colon & $\begin{array}{l}\text { AOM/DSS induced coloncancer in } \\
\text { male C57BL/6 mice }\end{array}$ & $\begin{array}{c}50 \mathrm{mg} / \mathrm{d} / \mathrm{kg} \text { b.w. mixed in diet for } \\
10 \text { days before the CACchallenge, } \\
\text { then for } 19 \text { or } 85 \text { days }\end{array}$ & $\begin{array}{l}\text { Tumor incidence } \downarrow \text {, Tumor } \\
\text { volume } \downarrow, \text { IL- } 6 \downarrow ; \text { STAT3 } \downarrow\end{array}$ & [36] \\
\hline $\begin{array}{l}\text { Ehrlich's ascites } \\
\text { Carcinoma (EAC) }\end{array}$ & $\begin{array}{l}\text { Male Swiss albino mice solid tumor } \\
\text { model with EAC cells }\end{array}$ & $\begin{array}{l}\text { Photodynamic therapywith } \\
\text { Embelin } 12.5 \mathrm{mg} / \mathrm{kg} \text { b.w. i.p. }\end{array}$ & $\begin{array}{c}\text { Tumor incidence } \downarrow \text {, Tumor } \\
\text { volume } \downarrow \text {, Myeloperoxidase } \downarrow \text {, } \\
\beta \text {-d-glucuronidase } \downarrow \text {, } \\
\text { Rhodanese } \uparrow, \text { Bcl- } 2 \downarrow ; \text { Bax } \uparrow\end{array}$ & [37] \\
\hline Liver & $\begin{array}{c}\text { DENA/PB induced } \\
\text { hepatocarcinogenesis in male } \\
\text { Wistar rats }\end{array}$ & $\begin{array}{c}50 \mathrm{mg} / \mathrm{kg} \text { b.w. per os(p.o.) for } \\
14 \text { weeks }\end{array}$ & Neoplastic nodules $\downarrow$, & [38] \\
\hline Pancreas & $\begin{array}{c}\text { Female C57BL/ } 6 \\
\text { Ectopic mouse model with H7 or } \\
\text { Panc } 02 \text { cells } \\
\text { Female C57BL/ } 6 \\
\text { Orthotopic mouse model with H7 } \\
\text { or Panc } 02 \text { cells }\end{array}$ & $\begin{array}{c}50 \mathrm{mg} / \mathrm{kg} \text { b.w. intraperitoneal } \\
\text { injection (i.p.) daily for two weeks } \\
50 \mathrm{mg} / \mathrm{kg} \text { b.w. i.p. every other day } \\
\text { for one week }\end{array}$ & $\begin{array}{l}\text { Tumor volume } \downarrow \text { Tumor } \\
\text { volume } \downarrow \text { Metastasis } \downarrow\end{array}$ & [39] \\
\hline
\end{tabular}

Table 2. Synergistic anti-cancer effects of embelin in vivo.

\begin{tabular}{|c|c|c|c|c|}
\hline Cancer Model & Animal Model & Dose & Outcome & References \\
\hline Breast & $\begin{array}{l}\text { Female nude mice xenograft models } \\
\text { of MDA-MB-231 cells }\end{array}$ & $\begin{array}{c}\text { Embelin } 10 \mathrm{mg} / \mathrm{kg} \text { b.w. and LY294002 } \\
10 \mathrm{mg} / \mathrm{kg} \text { b.w. i.p. twice weekly for } \\
\text { four weeks }\end{array}$ & $\begin{array}{c}\text { Tumor volume } \downarrow, \text { XIAP } \downarrow ; \\
\text { Bcl-2 } \downarrow ; \text { Bxl-xL } \downarrow \text { AKT } \downarrow ; \\
\text { caspase- } 3 \downarrow\end{array}$ & [40] \\
\hline Pancreas & $\begin{array}{l}\text { Male athymic nude mice xenograft } \\
\text { models of HPAF-II cells }\end{array}$ & $\begin{array}{l}\text { Ellagic acid } 150 \mathrm{mg} / \mathrm{kg} \text { diet, daily } \\
25 \mathrm{mg} / \mathrm{kg} \text { b.w. and Embelin } \\
450 \mathrm{mg} / \mathrm{kg} \text { diet, daily } 75 \mathrm{mg} / \mathrm{kg} \text { b.w. } \\
\text { for one week beforetumor } \\
\text { implantation, andthen for five weeks }\end{array}$ & $\begin{array}{l}\text { Tumor volume } \downarrow \text {, Tumor } \\
\text { cellularity } \downarrow\end{array}$ & [7] \\
\hline $\begin{array}{l}\text { Papillary Thyroid } \\
\text { Carcinoma }\end{array}$ & $\begin{array}{l}\text { Nude mice xenograft with } \\
\text { TPC1 cells }\end{array}$ & $\begin{array}{l}\text { Embelin } 10 \mathrm{mg} / \mathrm{kg} \text { b.w.and LY294002 } \\
10 \mathrm{mg} / \mathrm{kg} \text { b.w. i.p. twice weekly for } \\
\text { four weeks }\end{array}$ & $\begin{array}{c}\text { Tumor volume } \downarrow \text {, XIAP } \downarrow \text {; } \\
\text { p-AKT } \downarrow ; \text { caspase- } 3 \text { and }-8 \downarrow ; \\
\text { Bcl- } 2 \downarrow ; \text { Bxl-X1 } \downarrow\end{array}$ & [41] \\
\hline \multirow[t]{3}{*}{ Prostate } & $\begin{array}{l}\text { Male Balb/c nude mice xenograft } \\
\text { models of LNCaP cells }\end{array}$ & $\begin{array}{l}\text { Bicalutamide } 20 \mathrm{mg} / \mathrm{kg} \text { three times a } \\
\text { week and then embelin-loaded } \\
\text { micellesintratumoral injection from } \\
\text { day } 28\end{array}$ & Tumor volume $\downarrow$ & [42] \\
\hline & $\begin{array}{l}\text { Male athymic nu/nu mice } \\
\text { xenograft models of C4-2 cells }\end{array}$ & $\begin{array}{c}\text { CBDIV17 antiandrogen } 10 \mathrm{mg} / \mathrm{kg} \text { and } \\
\text { embelin } 10 \mathrm{mg} / \mathrm{kg} \text {-loaded micelles, } \\
\text { intratumoral injection on days } 0,3, \\
\text { and } 7\end{array}$ & Tumor volume $\downarrow$ & [43] \\
\hline & $\begin{array}{l}\text { Female athymic NCr-nu/nu mice } \\
\text { xenograft models of PC-3 cells }\end{array}$ & $\begin{array}{l}\text { X-ray radiation at } 2 \mathrm{~Gy} \text { fraction on } \\
\text { days } 1 \text { to } 5 \text { weekly for } 2 \text { weeks and } \\
\text { Embelin } 60 \mathrm{mg} / \mathrm{kg} \text { p.o. on days } 1 \text { to } \\
5 \text { weekly for three weeks }\end{array}$ & $\begin{array}{l}\text { Tumor volume } \downarrow \text {, Ki67 and } \\
\text { PCNA } \downarrow \text {, TUNEL } \uparrow ; \text { PARP } \\
\text { cleavage } \uparrow, \text { CD } 31 \downarrow\end{array}$ & [44] \\
\hline
\end{tabular}

\section{Apoptosis-Pathway Induction by Embelin in Cancer}

\subsection{Extrinsic Pathway}

Embelin has been reported to modulate the extrinsic apoptotic pathway and inhibit TNF- $\alpha$, TNF receptor-1, and TRADD gene expression [16]. Human breast-cancer cells treated with embelin have attenuated levels of TNF- $\alpha$ and the TNF- $\alpha$-converting enzyme [19]. TNF-related apoptosis-inducing ligand (TRAIL) is a part of the TNF superfamily, which is known to selectively induce apoptosis within cancer cells without being significantly toxic toward normal cells [45]. TRAIL is an apoptosis-inducing ligand, especially in tumor cells [46]. Several cancers have acquired resistance to interleukin-mediated apoptosis primarily because of reduced TRAIL-R1/-R2 expression, 
the over-expression of anti-apoptotic proteins like XIAP and c-FLIP, or elevated TRAIL decoy receptors TRAIL-R3/R4 [47]. Recent work has shown that embelin has the ability to restore the TRAIL sensitivity of cancer cells that are TRAIL-resistant. Embelin enhanced the TRAIL sensitivity by inhibition of XIAP in pancreatic cancer, nasopharyngeal carcinoma, and inflammatory breast-cancer cells. Embelin also sensitized malignant glioma cells to TRAIL-mediated apoptosis via down-regulating FLIP [48]. In A549 non-small-cell lung-cancer cells, embelin was shown to enhance TRAIL-mediated apoptosis via decreasing the levels of survivin, Bcl-2, and FLIP [49]. In addition, embelin sensitized human leukemia cells to TRAIL-induced apoptosis through the up-regulation of DR4 and DR5 [50]. These findings suggest that embelin can be applied in conjunction with other therapeutic modalities for cancer therapy.

\subsection{Intrinsic Pathway}

The intrinsic pathway is also known as the mitochondrial pathway because it depends on factors released from the mitochondria. This pathway is regulated by the Bcl2 family of proteins, including anti-apoptotic (e.g., XIAP, Mcl-1, Bcl-xL, and Bcl-2) and pro-apoptotic (e.g., Smac, Bak, Bid, and Bax) proteins [51]. The mitochondrial pathway is activated by intrinsic death stimuli, which causes cytochrome $c$ to be released from the mitochondria and the apoptosome complex (consisting of caspase-9, cytochrome c, and the apoptotic protease activating factor (Apaf1)) to be formed. The apoptosome activates caspase-9 which, in turn, activates caspase-3 [52]. It has been reported that embelin significantly induces apoptosis in a range of cancer cells via the mitochondria-dependent apoptosis pathway. Embelin induced apoptosis in human leukemia cells, which was mediated by the activation of caspase-dependent mechanisms that involved the down-regulation of XIAP [53]. XIAP is an important member of the inhibitors of apoptosis (IAP) family that is involved in cancer-cell survival [41,54]. XIAP inhibits both caspase-9 and -3, leading to suppression of apoptosis within cancer cells $[55,56]$. It has been shown that embelin promotes the release of cytochrome $C$ thereby promoting the activation of PARP cleavage and executioner caspase-3 in cancer cells [57]. With MCF-7 breast-cancer cells, it was demonstrated that embelin promotes the mitochondrial release of cytochrome C, leading to the activation of caspase- 9 and -3 ; there were no significant changes observed in the level of caspase-8 [58].

In brain glioma cells, embelin induced apoptosis and G0/G1-phase cell-cycle arrest. In addition, it modulated the shifting of Bcl-2 and Bax to prompt the mitochondrial release of cytochrome c, thereby activating the caspase proteins to induce apoptosis [59]. Furthermore, embelin induced the expression and oligomerization of voltage-dependent anion channel 1 , situated in the outer mitochondrial membrane, which can function as a significant part of the permeability-transition pore that could promote cytochrome $\mathrm{c}$ as well as apoptosis-inducing factor release [60]. The apoptotic effects of embelin were also investigated in human acute $\mathrm{T}$ cell lymphoma Jurkat cells. Cell treatment with embelin resulted in the cleavage of PARP, the activation of caspase- 3 and -9 , a reduction in XIAP, $\mathrm{Bcl}-\mathrm{xL}$, and Bcl-2, and a concomitant rise in Bax [61].

\subsection{Other Apoptotic Pathways}

The discovery of NF- $\mathrm{kB}$ (nuclear factor kappa-light-chain-enhancer of activated B cells) was prompted by a preliminary observation by David Baltimore in 1986 that a ubiquitously-expressed protein NF- $\mathrm{kB}$ was able to bind a short immunoglobulin kappa-light-chain enhancer DNA sequence. Since its initial discovery, NF- $\mathrm{kB}$ has been heavily studied and identified as having roles in the regulation of apoptosis and survival signaling, pro- and anti-inflammatory reactions, memory formation, cell-adhesion maintenance, and many aspects of the immune response, including viral-infection responses. Indeed, its central role in immune-response control and the orchestration of cytokine and inflammatory signaling has led many to describe NF- $\mathrm{kB}$ as the prototypical proinflammatory signaling pathway [62-68]. Embelin was found to inhibit the activation of NF-KB induced by TNF- $\alpha$ and several other carcinogenic and inflammatory agents, including lipopolysaccharide, interleukin- $1 \beta$, phorbol myristate acetate, hydrogen peroxide, cigarette-smoke 
condensate, and okadaic acid [16]. Embelin down-regulated the TNF- $\alpha$-induced expression of various NF- $\kappa B-d e p e n d e n t$ anti-apoptotic proteins in KBM-5 chronic myelogenous leukemia cells [16]. It was found that apoptosis induced by embelin in human glioma was mediated via the inhibition of NF- $\kappa B$ activity, which in turn occurred via reduction of the nuclear translocation of p65 through reducing the phosphorylation and proteasomal degradation of IkB- $\alpha$ [69]. Embelin could also sensitize HL-60 acute myeloid leukemia cells to TRAIL through the inactivation of NF- $\kappa B$ in in vitro and in vivo HL-60 xenograft models [70].

Recently, it was shown that embelin could modulate several pathways linked to apoptosis and cell growth, such as JAK/STAT, PI3K/AKT, p53, and p38 MAPK in gastric-cancer cells [71,72]. Embelin also attenuated cell invasion and proliferation, and induced apoptosis via inhibiting STAT3 and activating p53 signaling pathways within mouse pancreatic-cancer cells [39]. The tumor-suppressor protein p53 regulates several cellular processes, like apoptosis, proliferation, cell cycle, genome integrity, and DNA damage response $[73,74]$. Once active, cytoplasmic p53 translocates to the nucleus and can bind itself to regulatory DNA sequences, and activate the expression of target genes, such as cell-cycle inhibition, angiogenesis, and induction of apoptosis [75-77]. p53 is an important pro-apoptotic factor and tumor inhibitor, and many natural chemopreventive agents have been found to trigger apoptosis and cell-cycle arrest by activating p53, as well as its target genes [21,26]. Embelin attenuated cell proliferation, blocked metastatic migration, regulated the expression of caspases and Bcl-2, and triggered apoptosis (which was found to be mediated by p53) within MCF-7 breast-cancer cells [78]. Furthermore, embelin was found to inhibit mortalin-p53 interactions. The binding of embelin with mortalin/p53 releases free p53, which then translocates to the nucleus and initiates gene transcription that augments the growth suppression of breast-cancer cells [79].

XIAP prevents apoptosis through phosphatidylinositol 3-kinase (PI3K)-dependent inhibition of the caspase cascade [80]. There is possible involvement of the PI3K/AKT survival pathway in XIAP-mediated chemoresistance of ovarian-cancer cells [80]. PI3K was first discovered as a lipid kinase that phosphorylates phosphoinositides (PtdIns) at position 3 of the inositol ring. Several studies have reported on the role of PI3K as a pro-survival signaling molecule that can be activated by growth factors [81]. Upon activation, PI3K phosphorylates AKT in a serine/threonine residue, thereby activating the PI3K/AKT pathway [82-85]. The phosphorylated AKT subsequently inactivates Bad, a pro-apoptotic element of the Bcl-2 group [86]. In PC-3 prostate-cancer cells, embelin prevented the AKT/mTOR/S6K1 signaling cascade from being constitutively activated, which corresponded with substantial apoptosis being triggered, as evidenced by various biochemical assays [18,72]. In addition, the suppression of GSK-3 $\beta$ activation and AKT signaling is partly responsible for embelin's pro-apoptotic effect [60]. Embelin decreased the constitutive phosphorylation/activation levels of PI3K/AKT in bladder cancer, pancreatic cancer, and leukemia $[57,87,88]$, and inhibited cell growth by inducing apoptosis via the PI3K/AKT pathway. When embelin was used in combination treatment with either an AKT inhibitor or a PI3K inhibitor (LY294002), downstream caspase-3 and -9 experienced activation and cleavage, and PARP experienced cleavage. These results clearly demonstrate that suppressing the PI3K/AKT pathway and inhibiting XIAP results in more efficient apoptosis in diffuse, large B-cell lymphoma [54]. The combination of LY294002 and embelin also resulted in the synergistic induction of apoptosis in papillary thyroid carcinoma and breast-cancer cells, and the regression of tumor growth in vivo $[40,41]$. Therefore, embelin alone or in combination with inhibitors of the PI3K/AKT pathway may have therapeutic utility in cancers with upregulated XIAP expression.

STAT3 (signal transducer and activator of transcription 3), part of a group of six varied transcription factors, has been reported to be closely linked with the survival characteristics and aberrant growth of tumor cells [89-94]. Embelin suppressed STAT3's constitutive activation in several cancers, including human multiple myeloma (U266), head and neck squamous carcinoma (SCC4), and human prostate carcinoma (DU-145) [17]. Embelin also suppressed proliferation and augmented apoptosis dose-dependently within human pancreatic HPAF-II and MIA PaCa-2 cancer cells, and decreased the phosphorylation of STAT3 and the expression of surviving, its downstream target, within 
MIA PaCa-2 cells [7]. Furthermore, embelin dose-dependently suppressed the phosphorylation of STAT3 within mouse pancreatic H7 and Panc 02 tumor cells, both in vitro and in vivo [39,72].

\section{Autophagy Pathway Induced by Embelin in Cancer}

Autophagy is a conserved cellular process that regulates multiple physiological processes, is associated with several human ailments, and plays a pivotal role in self-defense against pathogen infections. Mechanistically, deregulated autophagy in cancer was reported in 1999, and more recently extensive attention has been paid to elucidating the paradoxical role of autophagy in tumor suppression and tumor promotion [95]. Autophagy is a genetically-programmed and evolutionarily-conserved catabolic pathway that induces a specific form of programmed cell death that is different from caspases-mediated apoptosis [96]. The persistent activation of autophagy also has a part in several biological processes, like cell growth and protein synthesis [96-102]. Embelin was shown to induce autophagy in human oral squamous carcinoma Ca9-22 cells. Beclin 1/Atg six is an important component in the formation of autophagic vesicles. The embelin-induced autophagic cell death of oral-cancer cells was mediated by LC3-II and the suppression of p62/SQSTM1 and Beclin-1, and was associated with cleavage formation of the Atg5-Atg12 complex and Beline-1 [1]. In addition, embelin's anti-cancer activity was mediated by the concomitant induction of both autophagy and apoptosis [1].

Autophagy and apoptosis are two of the most important physiological processes. Despite the marked differences in their mechanisms of action, they are highly interconnected and perform complex cross-talk in inducing apoptosis. It has been observed that the pro-apoptotic signals activate caspase-3. Activated caspases also degrade autophagy proteins such as Beclin 1, Atg5, and Atg7 by downregulating the autophagy response [103]. When autophagy is inhibited, the apoptotic pathway takes over, displaying characteristic chromatin condensation, nuclear fragmentation, and membrane blebbing [104]. Thus, the deregulated apoptotic pathway is often found in cancer cells, and in low-stress conditions autophagy is initiated as a pro-survival mechanism. However, in cancer cells, autophagy-induced cell death has been observed as an alternative mode of action [104,105]. Cross-talk between autophagy and apoptosis has also been reported, from upstream regulators to the core machinery [104]. When designing anti-cancer drugs such as embelin, which target autophagic mechanisms, two different strategies can be adopted: either trigger autophagy and augment its tumor-suppression properties or suppress autophagy and then induce apoptosis [106]. Overall, the proposed mechanisms underlying the anti-cancer activities of embelin are depicted in Figure 2 . In K562 and U937 leukemia cells, caspase inhibitor z-VAD-fmk reversed embelin-induced apoptosis, which suggests that apoptosis mediated by embelin is also partially mediated by caspases. In addition, embelin increased the expression of LC3-II in both K562 and U937 cells, indicating that embelin-induced cell death is associated with both autophagy and caspase-dependent apoptosis [57].

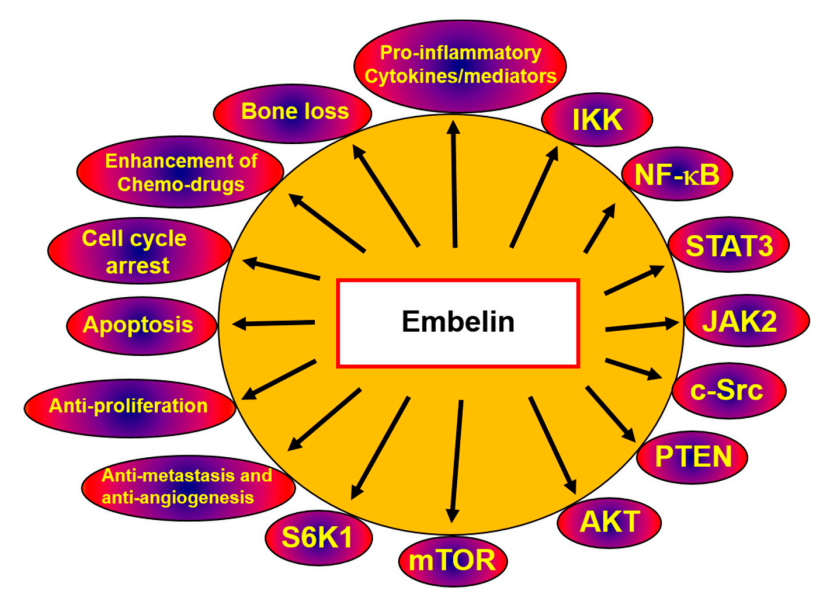

Figure 2. Proposed mechanisms of the potential anticancer activities of embelin. 


\section{Redox- and Non-Redox-Dependent Actions of Embelin}

Recent evidence suggests that the redox-modulating action of embelin is a mechanism responsible for the in vitro inhibition of COX. However, the redox mechanism on its own cannot account for embelin's activity. Molecular-modeling studies have revealed similar binding modes that are also similar to nonsteroidal anti-inflammatory drugs (NSAIDs), which are extensively employed for the treatment of chronic and acute inflammatory disorders [107]. In silico modeling suggested that embelin would initiate a hydrogen bond together with Tyr355, while the alkyl chain would fit into a hydrophobic binding pocket that would form, resulting in Tyr385 [107]. In HT-29 colon-cancer cells, embelin increased the amount of lipid peroxides with concomitant depletion of the total amount of glutathione S-transferase and GSH (reduced glutathione) activity, thereby increasing oxidative stress and the induction of apoptosis [108]. Embelin induced cytotoxicity in HL-60 dose-dependently by increasing the generation of intracellular oxidation and the oxidative stress [109]. A dose of $50 \mathrm{mg} / \mathrm{kg}$ of embelin lowered lipid peroxidation, stopped the fall in the hepatic glutathione antioxidant defense, and reduced the histological alterations caused by chemically-induced hepatocarcinogenesis in Wistar rats [4]. In another study, increasing concentrations of embelin decreased the levels of lipid peroxide and glutathione in fibrosarcoma cells [110]. Embelin can sensitize inflammatory breast-cancer cells to TRAIL-mediated apoptosis via shifting the cellular redox balance, an indication that ROS modulators represent a novel approach to the treatment of inflammatory breast cancer [111]. Embelin may also be used with photodynamic therapy (PDT), which employs photochemical reactions mediated via interaction with a photosensitizing agent for treating malignant tumors. Embelin in combination with PDT increased ROS accumulation in Ehrlich ascites carcinoma cells and induced apoptosis [112]. Similarly, in A549 lung-cancer cells, embelin can induce ROS activation and subsequently lead to the induction of apoptosis [113]. Therefore, redox imbalance and pro-oxidant pathways may also contribute to embelin-induced cancer-cell death.

\section{Embelin Derivatives Complex Functions as a Catalyst and as an Anti-Cancer Agent}

Quinonic compounds are found ubiquitously in nature and are mainly involved the transfer of hydrogen and electrons and they also form a big group of anticancer agents that are either in the preclinical or clinical development [114,115]. Embelin is a 1,4-benzoquinolic compound that has been shown to exhibit significant anti-cancer activities. Several studies have indicated the unique and remarkable role of novel embelin complexes that display fairly good catalytic activity for the reduction of molecular oxygen. One of the earliest study reported on the synthesis and structure of transition metal complexes of embelin, such as complexes of $\mathrm{Mn}(\mathrm{II}), \mathrm{Ni}(\mathrm{II}), \mathrm{Cu}(\mathrm{II})$, and $\mathrm{Zn}$ (II) with embelin [116]. Encapsulation of copper (II) complexes with two ligands of embelin was catalytically active and greatly increased the oxygen binding ability of the metal ion. This finding has far reaching consequences in the applications of gas purification [117]. In another recent report, new derivatives of embelin that have aromatic groups linked to the benzoquinone core via the Suzuki-Miyaura reaction were synthesized and tested for its XIAP inhibitory activity in cancer cells [118]. The benzoquinone core of embelin has been utilized to synthesize $\mathrm{O}-\mathrm{CH} 3$ and $\mathrm{O}-\mathrm{C} 2 \mathrm{H} 5$ groups. It was found that the embelin analogues possessed good pro-apoptotic activities against selected tumor cells [119]. A recent study by Evans et al. showed that embelin derivatives can be synthesized by Knoevenegal/Hetero-Diels-Alder domino reactions (DKHDA) $[120,121]$ and reported that the promising structural backbone for the synthesis of bioactive drug candidates [72]. In addition, several novel benzyl-piperidine derivatives of embelin showed potent anti-proliferative activities against a variety of breast, prostate, pancreatic and colon cancer cells and induced mitochondria mediated apoptosis [122]. Novel hydrophilic analogues of embelin consisting of 3 amine groups with differences in the length of the carbon chain was found to be cytotoxic to KERATIN-forming tumor cell line HeLa KB cancer cells [123]. Several other new embelin derivatives were also reported to have potent XIAP inhibitory activity [124]. In another recent report, embelin-derived rhodium $\mathrm{Rh}(\mathrm{III})$ and iridium $\mathrm{Ir}(\mathrm{III})$ metalla-rectangles derivatives inhibited 
the growth of DU-145 prostate cancer, A-549 lung cancer, and cervical cancer HeLa cells. In contrast there was a minimal effect on the growth of non-cancerous HEK-293 cells [125].

\section{Conclusions}

Embelin, a naturally-occurring benzoquinone, exhibits many anti-cancer properties in various cancer cells. Embelin induces apoptosis by targeting several signaling pathways, which differ considerably based on the origin of the cancer. Tumor cells employ multiple survival pathways to promote their initiation, progression, and metastasis. Accordingly, agents such as embelin, which can suppress multiple cellular and redox pathways, may have strong potential for cancer prevention and treatment. Targeting autophagy in cancer may be a feasible approach in cancer therapy, and, since autophagy has a part in the suppression of tumors, the use of embelin-induced autophagy could be a significant strategy for cancer prevention.

Acknowledgments: This work was supported by a grant from the National Research Foundation of Korea (NRF) funded by the Korean government (MSIP) (NRF-2015R1A4A1042399 and NRF-2016R1A6A3A11930941).

Author Contributions: J.-H.K., S.-G.L., W.M.Y., and J.-Y.U. designed and wrote the manuscript; S.M., M.K.S., G.S., and K.S.A. edited and finalized the manuscript for submission.

Conflicts of Interest: The authors declare no conflict of interest.

\section{References}

1. Lee, Y.J.; Park, B.S.; Park, H.R.; Yu, S.B.; Kang, H.M.; Kim, I.R. XIAP inhibitor embelin induces autophagic and apoptotic cell death in human oral squamous cell carcinoma cells. Environ. Toxicol. 2017, 32, 2371-2378. [CrossRef] [PubMed]

2. Rathinam, K.K.S.; Ramiah, N. Studies on the antifertility activity of embelin. J. Res. Indian Med. Yoga Homeopat. 1976, 11, 84-90.

3. Prakash, A.O. Short-Term Toxicity of Embelin in Female Rats. Phytother. Res. 1994, 8, 257-264. [CrossRef]

4. Sreepriya, M.; Bali, G. Effects of administration of Embelin and Curcumin on lipid peroxidation, hepatic glutathione antioxidant defense and hematopoietic system during $N$-nitrosodiethylamine/Phenobarbital-induced hepatocarcinogenesis in Wistar rats. Mol. Cell. Biochem. 2006, 284, 49-55. [CrossRef] [PubMed]

5. Johri, R.K.; Dhar, S.K.; Pahwa, G.S.; Sharma, S.C.; Kaul, J.L.; Zutshi, U. Toxicity studies with potassium embelate, a new analgesic compound. Indian J. Exp. Biol. 1990, 28, 213-217. [PubMed]

6. Poojari, R.; Gupta, S.; Maru, G.; Khade, B.; Bhagwat, S. Chemopreventive and hepatoprotective effects of embelin on $\mathrm{N}$-nitrosodiethylamine and carbon tetrachloride induced preneoplasia and toxicity in rat liver. Asian Pac. J. Cancer Prev. 2010, 11, 1015-1020. [PubMed]

7. Edderkaoui, M.; Lugea, A.; Hui, H.; Eibl, G.; Lu, Q.Y.; Moro, A.; Lu, X.; Li, G.; Go, V.L.; Pandol, S.J. Ellagic acid and embelin affect key cellular components of pancreatic adenocarcinoma, cancer, and stellate cells. Nutr. Cancer 2013, 65, 1232-1244. [CrossRef] [PubMed]

8. Zutshi, U.; Sharma, S.C.; Kaul, J.L.; Atal, C.K. Kinetic fate of potassium embelate, a non-narcotic centrally acting analgesic after oral and intravenous administration. Pharmacology 1990, 40, 179-184. [CrossRef] [PubMed]

9. Srinivas, N.; Narsimha Reddy, Y.; Goverdhan, P.; Venkateshwarlu, K. Development and validation of HPLC method for determination of Embelin in rat plasma and its application to pharmacokinetic study. J. Pharm. Res. 2011, 4, 3660-3663.

10. Gupta, S.K.U.; Sanyal, S.N. Biodistribution of embelin, a benzoquinone of male antifertility potential. Fitoterapia 1991, 62, 419-428.

11. Chitra, M.; Sukumar, E.; Suja, V.; Devi, C.S. Antitumor, anti-inflammatory and analgesic property of embelin, a plant product. Chemotherapy 1994, 40, 109-113. [CrossRef] [PubMed]

12. Kalyan Kumar, G.; Dhamotharan, R.; Kulkarni, N.M.; Mahat, M.Y.; Gunasekaran, J.; Ashfaque, M. Embelin reduces cutaneous TNF-alpha level and ameliorates skin edema in acute and chronic model of skin inflammation in mice. Eur. J. Pharmacol. 2011, 662, 63-69. [CrossRef] [PubMed] 
13. Bhandari, U.; Jain, N.; Pillai, K.K. Further studies on antioxidant potential and protection of pancreatic beta-cells by Embelia ribes in experimental diabetes. Exp. Diabetes Res. 2007, 2007, 15803. [CrossRef] [PubMed]

14. Singh, D.; Singh, R.; Singh, P.; Gupta, R.S. Effects of embelin on lipid peroxidation and free radical scavenging activity against liver damage in rats. Basic Clin. Pharmacol. Toxicol. 2009, 105, 243-248. [CrossRef] [PubMed]

15. Nikolovska-Coleska, Z.; Xu, L.; Hu, Z.; Tomita, Y.; Li, P.; Roller, P.P.; Wang, R.; Fang, X.; Guo, R.; Zhang, M.; et al. Discovery of embelin as a cell-permeable, small-molecular weight inhibitor of XIAP through structure-based computational screening of a traditional herbal medicine three-dimensional structure database. J. Med. Chem. 2004, 47, 2430-2440. [CrossRef] [PubMed]

16. Ahn, K.S.; Sethi, G.; Aggarwal, B.B. Embelin, an inhibitor of X chromosome-linked inhibitor-of-apoptosis protein, blocks nuclear factor-kappaB (NF-kappaB) signaling pathway leading to suppression of NF-kappaB-regulated antiapoptotic and metastatic gene products. Mol. Pharmacol. 2007, 71, $209-219$. [CrossRef] [PubMed]

17. Heo, J.Y.; Kim, H.J.; Kim, S.M.; Park, K.R.; Park, S.Y.; Kim, S.W.; Nam, D.; Jang, H.J.; Lee, S.G.; Ahn, K.S.; et al. Embelin suppresses STAT3 signaling, proliferation, and survival of multiple myeloma via the protein tyrosine phosphatase PTEN. Cancer Lett. 2011, 308, 71-80. [CrossRef] [PubMed]

18. Kim, S.W.; Kim, S.M.; Bae, H.; Nam, D.; Lee, J.H.; Lee, S.G.; Shim, B.S.; Kim, S.H.; Ahn, K.S.; Choi, S.H.; et al. Embelin inhibits growth and induces apoptosis through the suppression of Akt/mTOR/S6K1 signaling cascades. Prostate 2013, 73, 296-305. [CrossRef] [PubMed]

19. Dhanjal, J.K.; Nigam, N.; Sharma, S.; Chaudhary, A.; Kaul, S.C.; Grover, A.; Wadhwa, R. Embelin inhibits TNF-alpha converting enzyme and cancer cell metastasis: Molecular dynamics and experimental evidence. BMC Cancer 2014, 14, 775. [CrossRef] [PubMed]

20. Overholtzer, M.; Mailleux, A.A.; Mouneimne, G.; Normand, G.; Schnitt, S.J.; King, R.W.; Cibas, E.S.; Brugge, J.S. A nonapoptotic cell death process, entosis, that occurs by cell-in-cell invasion. Cell 2007, 131, 966-979. [CrossRef] [PubMed]

21. Shanmugam, M.K.; Kannaiyan, R.; Sethi, G. Targeting cell signaling and apoptotic pathways by dietary agents: Role in the prevention and treatment of cancer. Nutr. Cancer 2011, 63, 161-173. [CrossRef] [PubMed]

22. Hsieh, Y.S.; Yang, S.F.; Sethi, G.; Hu, D.N. Natural bioactives in cancer treatment and prevention. Biomed. Res. Int. 2015, 2015, 182835. [CrossRef] [PubMed]

23. Bishayee, A.; Sethi, G. Bioactive natural products in cancer prevention and therapy: Progress and promise. Semin. Cancer Biol. 2016, 40-41, 1-3. [CrossRef] [PubMed]

24. Galluzzi, L.; Aaronson, S.A.; Abrams, J.; Alnemri, E.S.; Andrews, D.W.; Baehrecke, E.H.; Bazan, N.G.; Blagosklonny, M.V.; Blomgren, K.; Borner, C.; et al. Guidelines for the use and interpretation of assays for monitoring cell death in higher eukaryotes. Cell Death Differ. 2009, 16, 1093-1107. [CrossRef] [PubMed]

25. Fulda, S. Apoptosis pathways and their therapeutic exploitation in pancreatic cancer. J. Cell. Mol. Med. 2009, 13, 1221-1227. [CrossRef] [PubMed]

26. Yang, S.F.; Weng, C.J.; Sethi, G.; Hu, D.N. Natural bioactives and phytochemicals serve in cancer treatment and prevention. Evid. Based Complement. Altern. Med. 2013, 2013, 698190. [CrossRef] [PubMed]

27. Hanahan, D.; Weinberg, R.A. The hallmarks of cancer. Cell 2000, 100, 57-70. [CrossRef]

28. Fesik, S.W. Promoting apoptosis as a strategy for cancer drug discovery. Nat. Rev. Cancer 2005, 5, 876-885. [CrossRef] [PubMed]

29. Shanmugam, M.K.; Lee, J.H.; Chai, E.Z.; Kanchi, M.M.; Kar, S.; Arfuso, F.; Dharmarajan, A.; Kumar, A.P.; Ramar, P.S.; Looi, C.Y.; et al. Cancer prevention and therapy through the modulation of transcription factors by bioactive natural compounds. Semin. Cancer Biol. 2016, 40-41, 35-47. [CrossRef] [PubMed]

30. Mizushima, N.; Komatsu, M. Autophagy: Renovation of cells and tissues. Cell 2011, 147, 728-741. [CrossRef] [PubMed]

31. Singh, S.S.; Vats, S.; Chia, A.Y.; Tan, T.Z.; Deng, S.; Ong, M.S.; Arfuso, F.; Yap, C.T.; Goh, B.C.; Sethi, G.; et al. Dual role of autophagy in hallmarks of cancer. Oncogene 2017, 37, 1142-1158. [CrossRef] [PubMed]

32. Mehrpour, M.; Esclatine, A.; Beau, I.; Codogno, P. Autophagy in health and disease. 1. Regulation and significance of autophagy: An overview. Am. J. Physiol. Cell Physiol. 2010, 298, C776-C785. [CrossRef] [PubMed]

33. Shao, Y.; Gao, Z.; Marks, P.A.; Jiang, X. Apoptotic and autophagic cell death induced by histone deacetylase inhibitors. Proc. Natl. Acad. Sci. USA 2004, 101, 18030-18035. [CrossRef] [PubMed] 
34. Kanzawa, T.; Zhang, L.; Xiao, L.; Germano, I.M.; Kondo, Y.; Kondo, S. Arsenic trioxide induces autophagic cell death in malignant glioma cells by upregulation of mitochondrial cell death protein BNIP3. Oncogene 2005, 24, 980-991. [CrossRef] [PubMed]

35. Dai, Y.; Qiao, L.; Chan, K.W.; Yang, M.; Ye, J.; Ma, J.; Zou, B.; Gu, Q.; Wang, J.; Pang, R.; et al. Peroxisome proliferator-activated receptor-gamma contributes to the inhibitory effects of Embelin on colon carcinogenesis. Cancer Res. 2009, 69, 4776-4783. [CrossRef] [PubMed]

36. Dai, Y.; Jiao, H.; Teng, G.; Wang, W.; Zhang, R.; Wang, Y.; Hebbard, L.; George, J.; Qiao, L. Embelin reduces colitis-associated tumorigenesis through limiting IL-6/STAT3 signaling. Mol. Cancer Ther. 2014, 13, 1206-1216. [CrossRef] [PubMed]

37. Joy, B.; Nishanth Kumar, S.; Soumya, M.S.; Radhika, A.R.; Vibin, M.; Abraham, A. Embelin (2,5-dihydroxy-3-undecyl-p-benzoquinone): A bioactive molecule isolated from Embelia ribes as an effective photodynamic therapeutic candidate against tumor in vivo. Phytomedicine 2014, 21, 1292-1297. [CrossRef] [PubMed]

38. Sreepriya, M.; Bali, G. Chemopreventive effects of embelin and curcumin against $\mathrm{N}$-nitrosodiethylamine/phenobarbital-induced hepatocarcinogenesis in Wistar rats. Fitoterapia 2005, 76, 549-555. [CrossRef] [PubMed]

39. Peng, M.; Huang, B.; Zhang, Q.; Fu, S.; Wang, D.; Cheng, X.; Wu, X.; Xue, Z.; Zhang, L.; Zhang, D.; et al. Embelin inhibits pancreatic cancer progression by directly inducing cancer cell apoptosis and indirectly restricting IL-6 associated inflammatory and immune suppressive cells. Cancer Lett. 2014, 354, 407-416. [CrossRef] [PubMed]

40. Hussain, A.R.; Siraj, A.K.; Ahmed, M.; Bu, R.; Pratheeshkumar, P.; Alrashed, A.M.; Qadri, Z.; Ajarim, D.; Al-Dayel, F.; Beg, S.; et al. XIAP over-expression is an independent poor prognostic marker in Middle Eastern breast cancer and can be targeted to induce efficient apoptosis. BMC Cancer 2017, 17, 640. [CrossRef] [PubMed]

41. Hussain, A.R.; Bu, R.; Ahmed, M.; Jehan, Z.; Beg, S.; Al-Sobhi, S.; Al-Dayel, F.; Siraj, A.K.; Uddin, S.; Al-Kuraya, K.S. Role of X-Linked Inhibitor of Apoptosis as a Prognostic Marker and Therapeutic Target in Papillary Thyroid Carcinoma. J. Clin. Endocrinol. Metab. 2015, 100, E974-E985. [CrossRef] [PubMed]

42. Danquah, M.; Li, F.; Duke, C.B., 3rd; Miller, D.D.; Mahato, R.I. Micellar delivery of bicalutamide and embelin for treating prostate cancer. Pharm. Res. 2009, 26, 2081-2092. [CrossRef] [PubMed]

43. Danquah, M.; Duke, C.B., 3rd; Patil, R.; Miller, D.D.; Mahato, R.I. Combination therapy of antiandrogen and XIAP inhibitor for treating advanced prostate cancer. Pharm. Res. 2012, 29, 2079-2091. [CrossRef] [PubMed]

44. Dai, Y.; Desano, J.; Qu, Y.; Tang, W.; Meng, Y.; Lawrence, T.S.; Xu, L. Natural IAP inhibitor Embelin enhances therapeutic efficacy of ionizing radiation in prostate cancer. Am. J. Cancer Res. 2011, 1, 128-143. [PubMed]

45. Gonzalvez, F.; Ashkenazi, A. New insights into apoptosis signaling by Apo2L/TRAIL. Oncogene 2010, 29, 4752-4765. [CrossRef] [PubMed]

46. Dai, X.; Zhang, J.; Arfuso, F.; Chinnathambi, A.; Zayed, M.E.; Alharbi, S.A.; Kumar, A.P.; Ahn, K.S.; Sethi, G. Targeting TNF-related apoptosis-inducing ligand (TRAIL) receptor by natural products as a potential therapeutic approach for cancer therapy. Exp. Biol. Med. (Maywood) 2015, 240, 760-773. [CrossRef] [PubMed]

47. Testa, U. TRAIL/TRAIL-R in hematologic malignancies. J. Cell. Biochem. 2010, 110, 21-34. [CrossRef] [PubMed]

48. Siegelin, M.D.; Gaiser, T.; Siegelin, Y. The XIAP inhibitor Embelin enhances TRAIL-mediated apoptosis in malignant glioma cells by down-regulation of the short isoform of FLIP. Neurochem. Int. 2009, 55, 423-430. [CrossRef] [PubMed]

49. Jiang, L.; Hao, J.L.; Jin, M.L.; Zhang, Y.G.; Wei, P. Effect of Embelin on TRAIL receptor 2 mAb-induced apoptosis of TRAIL-resistant A549 non-small cell lung cancer cells. Asian Pac. J. Cancer Prev. 2013, 14, 6115-6120. [CrossRef] [PubMed]

50. Hu, R.; Yang, Y.; Liu, Z.; Jiang, H.; Zhu, K.; Li, J.; Xu, W. The XIAP inhibitor Embelin enhances TRAIL-induced apoptosis in human leukemia cells by DR4 and DR5 upregulation. Tumour Biol. 2015, 36, 769-777. [CrossRef] [PubMed]

51. Galluzzi, L.; Larochette, N.; Zamzami, N.; Kroemer, G. Mitochondria as therapeutic targets for cancer chemotherapy. Oncogene 2006, 25, 4812-4830. [CrossRef] [PubMed]

52. Riedl, S.J.; Salvesen, G.S. The apoptosome: Signalling platform of cell death. Nat. Rev. Mol. Cell Biol. 2007, 8, 405-413. [CrossRef] [PubMed] 
53. Hu, R.; Zhu, K.; Li, Y.; Yao, K.; Zhang, R.; Wang, H.; Yang, W.; Liu, Z. Embelin induces apoptosis through down-regulation of XIAP in human leukemia cells. Med. Oncol. 2011, 28, 1584-1588. [CrossRef] [PubMed]

54. Hussain, A.R.; Uddin, S.; Ahmed, M.; Bu, R.; Ahmed, S.O.; Abubaker, J.; Sultana, M.; Ajarim, D.; Al-Dayel, F.; Bavi, P.P.; et al. Prognostic significance of XIAP expression in DLBCL and effect of its inhibition on AKT signalling. J. Pathol. 2010, 222, 180-190. [CrossRef] [PubMed]

55. Kashkar, H. X-linked inhibitor of apoptosis: A chemoresistance factor or a hollow promise. Clin. Cancer Res. 2010, 16, 4496-4502. [CrossRef] [PubMed]

56. Kaufmann, T.; Strasser, A.; Jost, P.J. Fas death receptor signalling: Roles of Bid and XIAP. Cell Death Differ. 2012, 19, 42-50. [CrossRef] [PubMed]

57. Prabhu, K.S.; Siveen, K.S.; Kuttikrishnan, S.; Iskandarani, A.; Tsakou, M.; Achkar, I.W.; Therachiyil, L.; Krishnankutty, R.; Parray, A.; Kulinski, M.; et al. Targeting of X-linked inhibitor of apoptosis protein and PI3-kinase/AKT signaling by embelin suppresses growth of leukemic cells. PLoS ONE 2017, 12, e0180895. [CrossRef] [PubMed]

58. Li, Y.; Li, D.; Yuan, S.; Wang, Z.; Tang, F.; Nie, R.; Weng, J.; Ma, L.; Tang, B. Embelin-induced MCF-7 breast cancer cell apoptosis and blockade of MCF-7 cells in the G2/M phase via the mitochondrial pathway. Oncol. Lett. 2013, 5, 1005-1009. [CrossRef] [PubMed]

59. Wang, A.; Zhang, B.; Zhang, J.; Wu, W.; Wu, W. Embelin-induced brain glioma cell apoptosis and cell cycle arrest via the mitochondrial pathway. Oncol. Rep. 2013, 29, 2473-2478. [CrossRef] [PubMed]

60. Park, N.; Baek, H.S.; Chun, Y.J. Embelin-Induced Apoptosis of Human Prostate Cancer Cells Is Mediated through Modulation of Akt and $\beta$-Catenin Signaling. PLoS ONE 2015, 10, e0134760. [CrossRef] [PubMed]

61. Zhu, X.L.; Jiang, L.; Qu, F.; Wang, Z.Y.; Zhao, L.M. Inhibitory effect of Embelin on human acute T cell lymphoma Jurkat cells through activation of the apoptotic pathway. Oncol. Lett. 2015, 10, 921-926. [CrossRef] [PubMed]

62. Orlowski, R.Z.; Baldwin, A.S., Jr. NF-kappaB as a therapeutic target in cancer. Trends Mol. Med. 2002, 8, 385-389. [CrossRef]

63. Solt, L.A.; May, M.J. The IkappaB kinase complex: Master regulator of NF-kappaB signaling. Immunol. Res. 2008, 42, 3-18. [CrossRef] [PubMed]

64. Gilmore, T.D. Introduction to NF-kappaB: Players, pathways, perspectives. Oncogene 2006, 25, 6680-6684. [CrossRef] [PubMed]

65. Sethi, G.; Tergaonkar, V. Potential pharmacological control of the NF-kappaB pathway. Trends Pharmacol. Sci. 2009, 30, 313-321. [CrossRef] [PubMed]

66. Li, F.; Sethi, G. Targeting transcription factor NF-kappaB to overcome chemoresistance and radioresistance in cancer therapy. Biochim. Biophys. Acta 2010, 1805, 167-180. [PubMed]

67. Li, F.; Zhang, J.; Arfuso, F.; Chinnathambi, A.; Zayed, M.E.; Alharbi, S.A.; Kumar, A.P.; Ahn, K.S.; Sethi, G. NF-kappaB in cancer therapy. Arch. Toxicol. 2015, 89, 711-731. [CrossRef] [PubMed]

68. Ningegowda, R.; Shivananju, N.S.; Rajendran, P.; Basappa; Rangappa, K.S.; Chinnathambi, A.; Li, F.; Achar, R.R.; Shanmugam, M.K.; Bist, P.; et al. A novel 4,6-disubstituted-1,2,4-triazolo-1,3,4-thiadiazole derivative inhibits tumor cell invasion and potentiates the apoptotic effect of TNFalpha by abrogating NF-kappaB activation cascade. Apoptosis 2017, 22, 145-157. [CrossRef] [PubMed]

69. Park, S.Y.; Lim, S.L.; Jang, H.J.; Lee, J.H.; Um, J.Y.; Kim, S.H.; Ahn, K.S.; Lee, S.G. Embelin induces apoptosis in human glioma cells through inactivating NF-kappaB. J. Pharmacol. Sci. 2013, 121, 192-199. [CrossRef] [PubMed]

70. Yang, T.; Lan, J.; Huang, Q.; Chen, X.; Sun, X.; Liu, X.; Yang, P.; Jin, T.; Wang, S.; Mou, X. Embelin sensitizes acute myeloid leukemia cells to TRAIL through XIAP inhibition and NF-kappaB inactivation. Cell Biochem. Biophys. 2015, 71, 291-297. [CrossRef] [PubMed]

71. Wang, D.G.; Sun, Y.B.; Ye, F.; Li, W.; Kharbuja, P.; Gao, L.; Zhang, D.Y.; Suo, J. Anti-tumor activity of the $\mathrm{X}$-linked inhibitor of apoptosis (XIAP) inhibitor embelin in gastric cancer cells. Mol. Cell. Biochem. 2014, 386, 143-152. [CrossRef] [PubMed]

72. Lu, H.; Wang, J.; Wang, Y.; Qiao, L.; Zhou, Y. Embelin and Its Role in Chronic Diseases. Adv. Exp. Med. Biol. 2016, 928, 397-418. [PubMed]

73. Bode, A.M.; Dong, Z. Post-translational modification of p53 in tumorigenesis. Nat. Rev. Cancer 2004, 4, 793-805. [CrossRef] [PubMed] 
74. Budram-Mahadeo, V.; Morris, P.J.; Latchman, D.S. The Brn-3a transcription factor inhibits the pro-apoptotic effect of p53 and enhances cell cycle arrest by differentially regulating the activity of the p53 target genes encoding Bax and p21(CIP1/Waf1). Oncogene 2002, 21, 6123-6131. [CrossRef] [PubMed]

75. Sherr, C.J.; Weber, J.D. The ARF/p53 pathway. Curr. Opin. Genet. Dev. 2000, 10, 94-99. [CrossRef]

76. Carr, A.M. Cell cycle. Piecing together the p53 puzzle. Science 2000, 287, 1765-1766. [CrossRef] [PubMed]

77. Lu, C.; El-Deiry, W.S. Targeting p53 for enhanced radio- and chemo-sensitivity. Apoptosis 2009, 14, 597-606. [CrossRef] [PubMed]

78. Sumalatha, K.R.; Abiramasundari, G.; Chetan, G.K.; Divya, T.; Sudhandiran, G.; Sreepriya, M. XIAP inhibitor and antiestrogen embelin abrogates metastasis and augments apoptosis in estrogen receptor positive human breast adenocarcinoma cell line MCF-7. Mol. Biol. Rep. 2014, 41, 935-946. [CrossRef] [PubMed]

79. Nigam, N.; Grover, A.; Goyal, S.; Katiyar, S.P.; Bhargava, P.; Wang, P.C.; Sundar, D.; Kaul, S.C.; Wadhwa, R. Targeting Mortalin by Embelin Causes Activation of Tumor Suppressor p53 and Deactivation of Metastatic Signaling in Human Breast Cancer Cells. PLoS ONE 2015, 10, e0138192. [CrossRef] [PubMed]

80. Asselin, E.; Mills, G.B.; Tsang, B.K. XIAP regulates Akt activity and caspase-3-dependent cleavage during cisplatin-induced apoptosis in human ovarian epithelial cancer cells. Cancer Res. 2001, 61, 1862-1868. [PubMed]

81. Panayotou, G.; Waterfield, M.D. The assembly of signalling complexes by receptor tyrosine kinases. Bioessays 1993, 15, 171-177. [CrossRef] [PubMed]

82. Coffer, P.J.; Woodgett, J.R. Molecular cloning and characterisation of a novel putative protein-serine kinase related to the cAMP-dependent and protein kinase C families. Eur. J. Biochem. 1991, 201, 475-481. [CrossRef] [PubMed]

83. Bellacosa, A.; de Feo, D.; Godwin, A.K.; Bell, D.W.; Cheng, J.Q.; Altomare, D.A.; Wan, M.; Dubeau, L.; Scambia, G.; Masciullo, V.; et al. Molecular alterations of the AKT2 oncogene in ovarian and breast carcinomas. Int. J. Cancer 1995, 64, 280-285. [CrossRef] [PubMed]

84. Singh, S.S.; Yap, W.N.; Arfuso, F.; Kar, S.; Wang, C.; Cai, W.; Dharmarajan, A.M.; Sethi, G.; Kumar, A.P. Targeting the PI3K/Akt signaling pathway in gastric carcinoma: A reality for personalized medicine? World J. Gastroenterol. 2015, 21, 12261-12273. [CrossRef] [PubMed]

85. Ong, P.S.; Wang, L.Z.; Dai, X.; Tseng, S.H.; Loo, S.J.; Sethi, G. Judicious Toggling of mTOR Activity to Combat Insulin Resistance and Cancer: Current Evidence and Perspectives. Front. Pharmacol. 2016, 7, 395. [CrossRef] [PubMed]

86. Datta, S.R.; Dudek, H.; Tao, X.; Masters, S.; Fu, H.; Gotoh, Y.; Greenberg, M.E. Akt phosphorylation of BAD couples survival signals to the cell-intrinsic death machinery. Cell 1997, 91, 231-241. [CrossRef]

87. Fu, X.; Pang, X.; Qi, H.; Chen, S.; Li, Y.; Tan, W. XIAP inhibitor Embelin inhibits bladder cancer survival and invasion in vitro. Clin. Transl. Oncol. 2016, 18, 277-282. [CrossRef] [PubMed]

88. Huang, M.; Tang, S.N.; Upadhyay, G.; Marsh, J.L.; Jackman, C.P.; Shankar, S.; Srivastava, R.K. Embelin suppresses growth of human pancreatic cancer xenografts, and pancreatic cancer cells isolated from KrasG12D mice by inhibiting Akt and Sonic hedgehog pathways. PLoS ONE 2014, 9, e92161. [CrossRef] [PubMed]

89. Aggarwal, B.B.; Sethi, G.; Ahn, K.S.; Sandur, S.K.; Pandey, M.K.; Kunnumakkara, A.B.; Sung, B.; Ichikawa, H. Targeting signal-transducer-and-activator-of-transcription-3 for prevention and therapy of cancer: Modern target but ancient solution. Ann. N. Y. Acad. Sci. 2006, 1091, 151-169. [CrossRef] [PubMed]

90. Subramaniam, A.; Shanmugam, M.K.; Perumal, E.; Li, F.; Nachiyappan, A.; Dai, X.; Swamy, S.N.; Ahn, K.S.; Kumar, A.P.; Tan, B.K.; et al. Potential role of signal transducer and activator of transcription (STAT)3 signaling pathway in inflammation, survival, proliferation and invasion of hepatocellular carcinoma. Biochim. Biophys. Acta 2013, 1835, 46-60. [CrossRef] [PubMed]

91. Siveen, K.S.; Sikka, S.; Surana, R.; Dai, X.; Zhang, J.; Kumar, A.P.; Tan, B.K.; Sethi, G.; Bishayee, A. Targeting the STAT3 signaling pathway in cancer: Role of synthetic and natural inhibitors. Biochim. Biophys. Acta 2014, 1845, 136-154. [CrossRef] [PubMed]

92. Chai, E.Z.; Siveen, K.S.; Shanmugam, M.K.; Arfuso, F.; Sethi, G. Analysis of the intricate relationship between chronic inflammation and cancer. Biochem. J. 2015, 468, 1-15. [CrossRef] [PubMed]

93. Chai, E.Z.; Shanmugam, M.K.; Arfuso, F.; Dharmarajan, A.; Wang, C.; Kumar, A.P.; Samy, R.P.; Lim, L.H.; Wang, L.; Goh, B.C.; et al. Targeting transcription factor STAT3 for cancer prevention and therapy. Pharmacol. Ther. 2016, 162, 86-97. [CrossRef] [PubMed] 
94. Wong, A.L.A.; Hirpara, J.L.; Pervaiz, S.; Eu, J.Q.; Sethi, G.; Goh, B.C. Do STAT3 inhibitors have potential in the future for cancer therapy? Expert Opin. Investig. Drugs 2017, 26, 883-887. [CrossRef] [PubMed]

95. Liang, X.H.; Jackson, S.; Seaman, M.; Brown, K.; Kempkes, B.; Hibshoosh, H.; Levine, B. Induction of autophagy and inhibition of tumorigenesis by beclin 1. Nature 1999, 402, 672-676. [CrossRef] [PubMed]

96. Mathew, R.; Karp, C.M.; Beaudoin, B.; Vuong, N.; Chen, G.; Chen, H.Y.; Bray, K.; Reddy, A.; Bhanot, G.; Gelinas, C.; et al. Autophagy suppresses tumorigenesis through elimination of p62. Cell 2009, 137, 1062-1075. [CrossRef] [PubMed]

97. Jin, S.; White, E. Role of autophagy in cancer: Management of metabolic stress. Autophagy 2007, 3, $28-31$. [CrossRef] [PubMed]

98. Pattingre, S.; Espert, L.; Biard-Piechaczyk, M.; Codogno, P. Regulation of macroautophagy by mTOR and Beclin 1 complexes. Biochimie 2008, 90, 313-323. [CrossRef] [PubMed]

99. Matsushita, M.; Suzuki, N.N.; Obara, K.; Fujioka, Y.; Ohsumi, Y.; Inagaki, F. Structure of Atg5.Atg16, a complex essential for autophagy. J. Biol. Chem. 2007, 282, 6763-6772. [CrossRef] [PubMed]

100. Satoo, K.; Noda, N.N.; Kumeta, H.; Fujioka, Y.; Mizushima, N.; Ohsumi, Y.; Inagaki, F. The structure of Atg4B-LC3 complex reveals the mechanism of LC3 processing and delipidation during autophagy. EMBO J. 2009, 28, 1341-1350. [CrossRef] [PubMed]

101. Jager, S.; Bucci, C.; Tanida, I.; Ueno, T.; Kominami, E.; Saftig, P.; Eskelinen, E.L. Role for Rab7 in maturation of late autophagic vacuoles. J. Cell Sci. 2004, 117, 4837-4848. [CrossRef] [PubMed]

102. Gonzalez-Polo, R.A.; Boya, P.; Pauleau, A.L.; Jalil, A.; Larochette, N.; Souquere, S.; Eskelinen, E.L.; Pierron, G.; Saftig, P.; Kroemer, G. The apoptosis/autophagy paradox: Autophagic vacuolization before apoptotic death. J. Cell Sci. 2005, 118, 3091-3102. [CrossRef] [PubMed]

103. Wang, K. Autophagy and apoptosis in liver injury. Cell Cycle 2015, 14, 1631-1642. [CrossRef] [PubMed]

104. Maiuri, M.C.; Zalckvar, E.; Kimchi, A.; Kroemer, G. Self-eating and self-killing: Crosstalk between autophagy and apoptosis. Nat. Rev. Mol. Cell Biol. 2007, 8, 741-752. [CrossRef] [PubMed]

105. Bursch, W.; Ellinger, A.; Kienzl, H.; Torok, L.; Pandey, S.; Sikorska, M.; Walker, R.; Hermann, R.S. Active cell death induced by the anti-estrogens tamoxifen and ICI 164384 in human mammary carcinoma cells (MCF-7) in culture: The role of autophagy. Carcinogenesis 1996, 17, 1595-1607. [CrossRef] [PubMed]

106. Yang, Z.J.; Chee, C.E.; Huang, S.; Sinicrope, F.A. The role of autophagy in cancer: Therapeutic implications. Mol. Cancer Ther. 2011, 10, 1533-1541. [CrossRef] [PubMed]

107. Landa, P.; Kutil, Z.; Temml, V.; Vuorinen, A.; Malik, J.; Dvorakova, M.; Marsik, P.; Kokoska, L.; Pribylova, M.; Schuster, D.; et al. Redox and non-redox mechanism of in vitro cyclooxygenase inhibition by natural quinones. Planta Med. 2012, 78, 326-333. [CrossRef] [PubMed]

108. Sumalatha, K.; Gowda, M.; Meenakshisundaram, S. ROS-mediated induction of apoptosis by benzoquinone embelin in human colon adenocarcinoma cells HT-29. J. Complement. Integr. Med. 2017, 14. [CrossRef] [PubMed]

109. Yang, Y.; Hu, R.; Zhu, K.; Li, Y.; Li, J.; Miao, M.; Wang, H.; Yao, K.; Liu, Z. Involvement of oxidative stress in embelin-induced cell death in leukemia HL-60 cells. Zhonghua Xue Ye Xue Za Zhi 2015, 36, 465-468. [PubMed]

110. Chitra, M.; Sukumar, E.; Devi, C.S. $\left[{ }^{3} \mathrm{H}\right]$-thymidine uptake and lipid peroxidation by tumor cells on embelin treatment: An in vitro study. Oncology 1995, 52, 66-68. [CrossRef] [PubMed]

111. Allensworth, J.L.; Aird, K.M.; Aldrich, A.J.; Batinic-Haberle, I.; Devi, G.R. XIAP inhibition and generation of reactive oxygen species enhances TRAIL sensitivity in inflammatory breast cancer cells. Mol. Cancer Ther. 2012, 11, 1518-1527. [CrossRef] [PubMed]

112. Joy, B.; Kumar, S.N.; Radhika, A.R.; Abraham, A. Embelin (2,5-Dihydroxy-3-undecyl-p-benzoquinone) for photodynamic therapy: Study of their cytotoxicity in cancer cells. Appl. Biochem. Biotechnol. 2015, 175, 1069-1079. [CrossRef] [PubMed]

113. Avisetti, D.R.; Babu, K.S.; Kalivendi, S.V. Activation of p38/JNK pathway is responsible for embelin induced apoptosis in lung cancer cells: Transitional role of reactive oxygen species. PLoS ONE 2014, 9, e87050. [CrossRef] [PubMed]

114. Ravelo, A.G.; Estévez-Braun, A.; Chávez-Orellana, H.; Pérez-Sacau, E.; Mesa-Siverio, D. Recent Studies on Natural Products as Anticancer Agents. Curr. Top. Med. Chem. 2004, 4, 241-265. [CrossRef] [PubMed]

115. Jiménez-Alonso, S.; Chávez, H.; Estévez-Braun, A.; Ravelo, A.G.; Tapia, A. An efficient synthesis of embelin derivatives through domino Knoevenagel hetero Diels-Alder reactions under microwave irradiation. Tetrahedron 2008, 64, 8938-8942. [CrossRef] 
116. Abdul Rasheed, K.K.; Chacko, J.; Nambisan, P.N.K. Thermal, spectral and magnetic studies on some transition metal complexes of embelin. Polyhedron 1983, 2, 293-299. [CrossRef]

117. Abraham, R.; Yusuff, K.K.M. Copper(II) complexes of embelin and 2-aminobenzimidazole encapsulated in zeolite Y-potential as catalysts for reduction of dioxygen. J. Mol. Catal. A Chem. 2003, 198, 175-183. [CrossRef]

118. Viault, G.; Gree, D.; Das, S.; Yadav, J.S.; Gree, R. Synthesis of a Focused Chemical Library Based on Derivatives of Embelin, a Natural Product with Proapoptotic and Anticancer Properties. Eur. J. Org. Chem. 2011, 2011, 1233-1241. [CrossRef]

119. Viault, G.; Babu, K.S.; Gautier, F.; Barille-Nion, S.; Juin, P.; Tasseau, O.; Gree, R. Hemisynthesis of selected embelin analogs and investigation of their proapoptotic activity against cancer cells. Med. Chem. 2013, 9, 1028-1034. [CrossRef] [PubMed]

120. Martin-Acosta, P.; Feresin, G.; Tapia, A.; Estevez-Braun, A. Microwave-Assisted Organocatalytic Intramolecular Knoevenagel/Hetero Diels-Alder Reaction with O-(Arylpropynyloxy)-Salicylaldehydes: Synthesis of Polycyclic Embelin Derivatives. J. Org. Chem. 2016, 81, 9738-9756. [CrossRef] [PubMed]

121. Pena, R.; Martin, P.; Feresin, G.E.; Tapia, A.; Machin, F.; Estevez-Braun, A. Domino Synthesis of Embelin Derivatives with Antibacterial Activity. J. Nat. Prod. 2016, 79, 970-977. [CrossRef] [PubMed]

122. Singh, B.; Guru, S.K.; Sharma, R.; Bharate, S.S.; Khan, I.A.; Bhushan, S.; Bharate, S.B.; Vishwakarma, R.A. Synthesis and anti-proliferative activities of new derivatives of embelin. Bioorg. Med. Chem. Lett. 2014, 24, 4865-4870. [CrossRef] [PubMed]

123. Lamblin, M.; Sallustrau, A.; Commandeur, C.; Cresteil, T.; Felpin, F.; Dessolin, J. Synthesis and biological evaluation of hydrophilic embelin derivatives. Tetrahedron 2012, 68, 4655-4663. [CrossRef]

124. Chen, J.; Nikolovska-Coleska, Z.; Wang, G.; Qiu, S.; Wang, S. Design, synthesis, and characterization of new embelin derivatives as potent inhibitors of X-linked inhibitor of apoptosis protein. Bioorg. Med. Chem. Lett. 2006, 16, 5805-5808. [CrossRef] [PubMed]

125. Gupta, G.; Kumar, J.M.; Garci, A.; Nagesh, N.; Therrien, B. Exploiting natural products to build metalla-assemblies: The anticancer activity of embelin-derived $\mathrm{Rh}(\mathrm{III})$ and $\mathrm{Ir}(\mathrm{III})$ metalla-rectangles. Molecules 2014, 19, 6031-6046. [CrossRef] [PubMed]

Sample Availability: Samples of the compounds are not available from the authors.

(C) 2018 by the authors. Licensee MDPI, Basel, Switzerland. This article is an open access article distributed under the terms and conditions of the Creative Commons Attribution (CC BY) license (http:/ / creativecommons.org/licenses/by/4.0/). 